\title{
Editorial
}

Pathobiology

Pathobiology 2007;74:197

DOI: $10.1159 / 000104444$

\section{Tissue Banking: Its Significance in Modern Medicine}

Normal and diseased tissues contain an enormous wealth of information with regard to differentiation, morphogenesis as well as normal and abnormal functions. The scientific yield grows with the sophistication of the analytical methodology used. However, even simple morphology (light microscopy) based on routinely stained tissue sections is extremely valuable not only in the assessment of diagnosis, etiology and prognosis of disease processes but also in basic research, if morphologic features are correctly interpreted, particularly in the context of clinical information. Modern molecular biotechnology further enhances the practical and scientific harvest. DNA and RNA can be isolated from the tissue, its encoded complex information analyzed using highthroughput assays and related to structure and function by immunohistochemically demonstrating gene products. Moreover, experimental reproduction of genetic alterations in animals and in tissue culture cells provides the opportunity to ever further explore basic principles underlying normal and diseased function. Biobanks with collections of normal and abnormal frozen and fixed, paraffin-embedded tissues supplemented with blood samples, other body fluids and even cultured cells derived from various tissues and related clinical data play an increasingly important role in clinically oriented research. Gene expression profiling and protein analysis techniques are now successfully adapted to fixed and embedded archival tissues and allow identification of disease-associated genes and their products, which sets the stage for discovery of new disease markers and drug tar- gets. Moreover, more precise knowledge of drug effects based on gene analysis allows the assessment of the risks of side effects, already prior to expensive and potentially harmful clinical trials. However, in addition to the medical and scientific advantages of biobanks, financial, ethical, legal and social aspects have to be considered. In this special issue of Pathobiology, biobanking is highlighted from different perspectives, and useful information is provided on a large scale. Gassner discusses legal aspects, trends and perspectives in the governance of biobanks, particularly with respect to the links between research and social and political requirements which play an increasingly decisive role in the management of these institutions. The importance of biobanking for epidemiologic and clinical research and public health is the subject of the contributions by Brand and Probst-Hensch, Clark, Borisch, Riegman et al., and Ponzoni et al. Practical applications and experiences are discussed by Morente et al., Schäfer and Lehr, Hansson, and Womack et al.

Pathology plays a central and decisive role in the establishment, expansion and administration of highquality tissue banks since their value and suitability critically depend on the preservation and correct evaluation of the tissue samples, in addition to the clinical history of the patients. In my opinion, it is, therefore, imperative that tissue banks are primarily associated with pathology institutes in close cooperation with clinical disciplines.

Helmut Denk, Graz

\begin{tabular}{ll}
\hline KARGER & (c) 2007 S. Karger AG, Basel \\
Fax +41 61 306 1234 & \\
$\begin{array}{l}\text { E-Mail karger@karger.ch } \\
\text { www.karger.com }\end{array}$ & $\begin{array}{l}\text { Accessible online at: } \\
\text { www.karger.com/pat }\end{array}$
\end{tabular}

